\title{
Antecedents of low carbon emissions supply chains
}

Low carbon emissions supply chains

\author{
Zongwei Luo
}

Southern University of Science and Technology, Guangdong, China

\author{
Angappa Gunasekaran
}

Charlton College of Business, University of Massachusetts, Dartmouth, Massachusetts, USA

Rameshwar Dubey

Montpellier Business School, Montpellier, France

Stephen J. Childe

Plymouth Business School, Plymouth University, Plymouth, UK, and

Thanos Papadopoulos

Kent Business School, University of Kent, Canterbury, UK

\begin{abstract}
Purpose - A low-carbon economy is the pressing need of the hour. Despite several efforts taken by the government and large corporations, there is still research to be conducted exploring the role of top management commitment in translating external pressures into responses that help to build low-carbon emissions in supply chains.

Design/methodology/approach - The authors have grounded their framework in institutional theory, agency theory and contingency theory. On the basis of existing literature, four hypotheses were drawn. To test these hypotheses, a questionnaire was developed and pre-tested. Finally, statistical analyses were performed to test the research hypotheses using 176 samples gathered using a pre-tested questionnaire following Dillman's (2007) total design test method.

Findings - The results suggest that coercive pressures and mimetic pressures under the mediating effect of top management commitment have a significant influence on organizational response to low-carbon emissions. The authors further note that supply base complexity has moderating effects on the link between top management commitment and organizational response towards low-carbon emissions.

Originality/value - This study offers valuable insights to those managers and environmental consultants who view supply base complexity as a limitation. However, the results indicate that supply base complexity may help to enhance the effectiveness of the top management commitment on organizational response towards low-carbon emissions.
\end{abstract}

Keywords Institutional theory, Environmental sustainability, Top management commitment, Carbon emissions, Contingent theory, Supply base complexity

Paper type Research paper

(C) Zongwei Luo, Angappa Gunasekaran, Rameshwar Dubey, Stephen J. Childe and Thanos Papadopoulos. Published by Emerald Publishing Limited. This article is published under the Creative Commons Attribution (CC BY 4.0) licence. Anyone may reproduce, distribute, translate and create derivative works of this article (for both commercial \& non-commercial purposes), subject to full attribution to the original publication and authors. The full terms of this licence may be seen at http://creativecommons.org/licences/by/4.0/legalcode

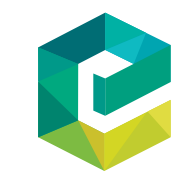




\section{IJCCSM 9,5}

\section{Introduction}

The rapid change in climate has affected business strategies significantly (Hoffman, 2005; Shaw et al., 2013; Fang et al., 2013; Montoya-Torres et al., 2015). The growing understanding of the need to develop resilience and sustainability (Fahimnia and Jabbarzadeh, 2016) has put pressure on traditional supply chains to meet the needs of a low-carbon economy (Norton et al., 2015). Supply chain design can help firms realize benefits in terms of reduced inventories and cost, high responsiveness and improved strategic focus in terms of design, execution and capital investments (Melnyk et al., 2014). In recent years, in the drive to achieve operational efficiencies and keep supply chains lean, organizations have exposed themselves to multiple risks associated with supply chain networks (Chopra and Sodhi, 2014), such as over-reliance on single suppliers or single logistics service providers. Bode et al. (2011) noted that in recent years, supply chains have been exposed to greater vulnerabilities owing to tighter coupling, increased complexities, reduced inventory levels and ever-greater increasing geographic dispersion. Guha-Sapir et al. (2012) further argued that the rapid increase in the frequency and impact of disruptions may be ascribed to a rise in events such as natural disasters that are beyond managerial control. For example, during 2011, when the Tsunami struck Japan, corporations were not prepared for one of the century's deadliest challenges. The impact of the Japan Tsunami on the world economy was much larger than what it would have been if it had happened during 1970s to 1980s. Organizations based in the USA and European countries were most affected, as the majority of automobile components and electronics goods are produced and supplied globally from Japan (Chopra and Sodhi, 2014). After 2011, extensive flooding in Thailand had severely impacted the manufacturing supply chains. Dell and HP were badly impacted, as nearly onethird of the hard disks are produced in Thailand. Following the globally increasing frequency and impact of natural disasters events, the CEOs of large corporations have expressed their serious concerns about the slowing down of economies, natural disasters in the Far East and emerging environmental regulations in different parts of the world (Jackson, 2014). Pacala and Socolow (2004) argue, among others, the prevailing view that human economic activities have been the single major cause for rapid change in climate. To achieve revolutionary change, the industry activities that produce carbon emissions need to be reduced significantly without impacting on economic growth. CDP (2015) has noted that, on average, 50 per cent of the total carbon emissions comes from each corporation's supply chain. Norton et al. (2015) further noted the pressing need for low-carbon supply chains.

While there is a rich body of literature focusing on low-carbon supply chains (Hua et al., 2011; Hitchcock, 2012; Benjaafar et al., 2013; Shaw et al., 2013), research on drivers of low-carbon supply chains is scant (Zhao et al., 2012). Existing studies focus mainly on green supply chain management (GSCM) implementation using organizational theories (Sarkis et al., 2011). There are few studies utilizing institutional theory to understand the role of external pressures on supply chain members to commit to reducing carbon emissions in the supply chain (Kauppi, 2013). However, following Zhu et al. (2007) and Zhu and Sarkis' (2007) arguments that institutional pressures have a significant influence on GSCM practices, researchers investigating developing countries such as India (Dubey et al., 2015) and Brazil (Seles et al., 2016) have further supported the institutional view. However, even though institutional theory has emerged as a powerful theory to provide an explanation of organizational action in response to institutional pressures, it has often been criticized as largely being used to explain both the persistence and the homogeneity of institutions (Dacin et al., 2002). Dacin et al. (2002) have noted that the notion of institutional change may offer a better explanation. Following criticism of institutional theory, researchers (Greenwood and Hinings, 1996; Delmas and Toffel, 2008) have argued to include 
intra-organizational dynamics within the institutional framework. Following Colwell and Joshi's (2013) arguments, we have incorporated top management commitment as an important construct within the institutional framework. Hence, we address the first research question:

$R Q 1$. What are the effects of institutional pressures and top management commitment on the low-carbon emission?

We follow Boyd et al. (2012) and Eckstein et al.'s (2015) arguments that direct effect on performance is often crucial, but it is not sufficient enough to explain business complexities. Furthermore, following the arguments of Sousa and Voss (2008), we ground our discussion on the view that the impacts of institutional pressures may be contingent upon specific conditions (Eckstein et al., 2015, cf. Sousa and Voss, 2008). This view stems from contingency theory (CT) (Donaldson, 2001). For this we adopt CT as a theoretical lens to examine the contextual conditions under which the institutional pressures under the mediating role of the top management are effective.

Supply base complexity has been recognized as a key managerial concern (BrandonJones et al., 2014) and a critical moderating factor. In this regard, we may assume that supply base complexity may enhance or hamper the effectiveness of the institutional pressures under the mediating effect of top management commitment (TMC). However, such significant effects have not been addressed in the existing literature. In this study, we focus on supply base complexity as a key facet of low-carbon supply chain. In the past, scholars have noted that supply base complexity relates to the number of suppliers (scale complexity), delivery reliability of suppliers (delivery complexity), differentiation between suppliers and geographic dispersion (Vachon and Klassen, 2002; Choi and Krause, 2006; Caridi et al., 2010; Brandon-Jones et al., 2014). The complexity increases as organizations utilize higher number of suppliers, as there are additional responsibilities of managing relationships, alongside additional information and product flows to oversee (Bozarth et al., 2009; Brandon-Jones et al., 2014). On the other hand, delivery with longer lead times further increases the complexity (Chen et al., 2000). Choi and Krause (2006) argue that differences in terms of cultural, practical and technical differences increase complexity. Finally, geographic dispersion may enhance complexity in terms of cultural and linguistic differences (Stringfellow et al., 2008), unpredictable quality (Gray et al., 2011) and variable lead times (Holweg et al., 2011). Hence, we argue that each dimension of complexity may generate uncertainty, and if the institutional pressures are not properly translated into desired actions, low-carbon benefits in the supply chain may not be effectively realized. We therefore investigate supply base complexity as our next research question:

$R Q 2$. What are the effects of supply base complexity on the relationships between TMC and low-carbon emission?

We answer these research questions based on a sample of 176 Indian manufacturing firms, using appropriate multivariate statistical tools. In doing so, we offer two major contributions to the existing literature. First, building on work by Zhu et al. (2007) and Zhu and Sarkis (2007), we argue that a mediating role of human agents may help to translate pressures into desired actions. Second, we build upon prior research (Zhu et al., 2007, Zhu and Sarkis, 2007; Seles et al., 2016) by adding contingent effects of supply base complexity on the effect of TMC on low-carbon emissions. With this we can address how supply base complexity may explain the different levels of institutional pressures' influence on lowcarbon emissions.
Low carbon emissions supply chains 
IJCCSM

9,5

\section{0}

The remainder of the paper is structured as follows. First, we describe underpinning theories. Second, we present our theoretical framework and draw testable hypotheses. Third, we describe our research design. Fourth, we present our data analyses and results. Finally, we discuss the theoretical contributions, managerial implications, limitations and future research directions.

\section{Underpinning theories}

We have grounded our hypothesized framework (Figure 1) in three theories:

(1) institutional theory (DiMaggio and Powell, 1983);

(2) TMC (Liang et al., 2007); and

(3) CT (Donaldson, 2001).

In the past decade, institutional theory has emerged as a powerful theory to account for the influence of external institutions on organizational decision-making and outcomes (Kauppi, 2013). We argue that institutional pressures retain their influence on the action of managers to reduce the negative influence of the carbon emissions in a supply chain. However, the direct effect of institutional pressures may not have a significant impact on the behaviour of the managers within the organizations. Thus, we argue that TMC may help to translate the influence of institutional pressures into desired actions to reduce the carbon emissions in a supply chain resulting from various supply chain activities. We follow Sousa and Voss' (2008) arguments that the impact of the institutional pressures under the mediating effect of TMC may be contingent upon specific conditions, as the direct effect on environmental performance may not be significant.

\subsection{Institutional isomorphism and low-carbon emissions}

Institutional theory explains the influence of external social, technical and political environments on organizational behaviour such as commitment towards low-carbon emissions (Zhu et al., 2007, Zhu and Sarkis, 2007; Dubey et al., 2015). Other organizational theories such as the resource-based view (RBV) (Barney, 1991; Grant, 1991) suffer from context insensitivity (Ling-Yee, 2007). Oliver (1997) has noted that despite RBV's popularity, the theory has never looked beyond the properties of the resources and resource markets to explain enduring firm heterogeneity. Transaction cost economics (Williamson, 1981) argues that behaviour of the supply chain members is purely guided by limited rationality and opportunistic behaviour. However, on the other hand, institutional theory posits that

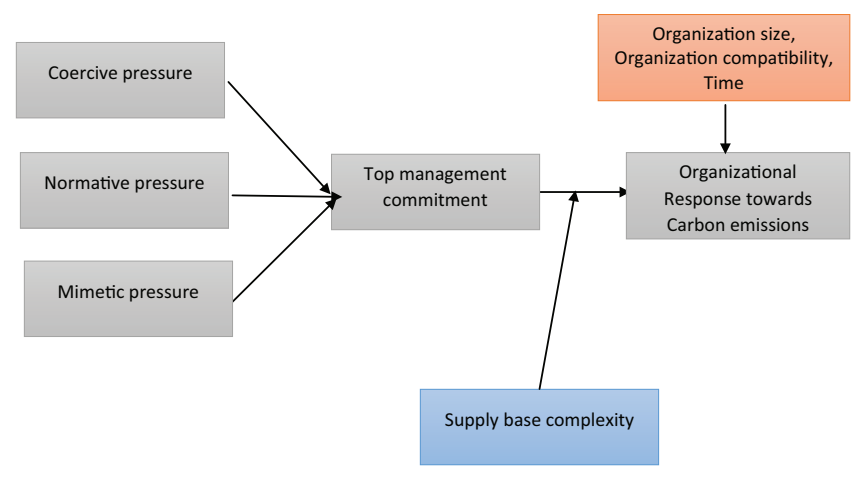

Figure 1. Hypothesized framework 
structural and behavioural changes in the organizations are driven less by competition and efficiency, but more by the need for legitimacy. The drive for legitimacy in the organization giving rise to institutional isomorphism (DiMaggio and Powell, 1983).

DiMaggio and Powell (1983) argue that there are three types of institutional pressures: coercive, normative and mimetic. Coercive isomorphism results when organizations accept formal and external pressures imposed on them. They may arise from government regulations and policies and from industry and professional networks and associations, or in the form of competitive necessity within an industry or market segment (Liang et al., 2007).

Normative isomorphism occurs as a result of professionalization defined as:

[...] the collective struggle of members of an occupation to define the conditions and methods of their work, to control the production of the future member professionals, and to establish a cognitive base and legitimization for their occupational autonomy (DiMaggio and Powell, 1983).

Mimetic isomorphism arises as a result of organizations responding to uncertainty by mimicking the actions of other successful organizations. DiMaggio and Powell (1983) argue that when organizations have limited understanding of the technologies, or when their organizational goals are ambiguous, or when the environment creates uncertainty, they may model themselves upon other organizations perceived to be legitimate or successful. Staw and Epstein (2000) argue that mimicry action is often associated with the bandwagon effect, whereas Liang et al. (2007) note that mimetic isomorphism has significant influence in organizational decision-making processes.

\subsection{Top management commitment and low-carbon emissions}

Zhu and Sarkis (2007) argue that institutional theory may predict institutional isomorphism; however, organizations have reflected diversity with respect to the degree of success in terms of reduction of carbon emissions in a supply chain. To study this diversity, we posit that top management is the primary human agent that translates the external pressures into desired managerial actions such as changing organizational structures and establishing policies based on the beliefs of institutional perspectives. Weaver et al. (1999) argue that external pressures for social performance encourage easily decoupled processes, but TMC can encourage both easily decoupled and integrated processes. Ageron et al. (2012) argue that TMC plays a significant role in sustainable supply chain management. Weaver et al. (1999) in the context of social performance and others in the context of environmental performance (Colwell and Joshi, 2013) argue about the mediating role of TMC; however, currently, empirical testing is scant, giving us the impetus for this paper.

\subsection{Supply base complexity, top management commitment and low-carbon emissions}

Gupta et al. (1994) argue that integration of CT with institutional theory can offer better explanation to control and coordination. CT is a mid-range theory that involves identifying and matching context settings with form settings (Hambrick, 1983; Eckstein et al., 2015). CT argues that firms should adapt structures and processes to achieve fit with the environment to attain superior performance (Donaldson, 2001). We further build upon Gupta et al.'s (1994) arguments that institutional pressures under the mediating effect of TMC may impact carbon emissions in supply chains under particular contingencies. Our study responds to the challenge to examine the contingent effect of supply base complexity on the relationship between TMC and low-carbon emissions. Colwell and Joshi (2013) argue that institutional pressures under efficient and effective guidance of committed managers may help reduce carbon emissions; however, the contingent conditions under which the influence of TMC
Low carbon emissions supply chains 


\section{IJCCSM 9,5}

may have an enhanced effect on low-carbon emissions are still underdeveloped. Therefore, we address this gap.

\section{Theoretical framework and hypotheses development}

Based on our theoretical proposition that TMC mediates the effect of institutional pressures on low-carbon emission, under the moderating influence of supply base complexity, we developed our hypothesized framework (Figure 1). We do not exclude the possibility that other factors may have a confounding effect on dependent variables. Hence, we have controlled the effect of those confounding variables (Figure 1). Here we conceptualize carbon emissions as a third-order reflective construct, the TMC as a second-order reflective construct and institutional pressures as a multidimensional first-order reflective construct. We propose four research hypotheses grounded in the environmental sustainability literature focusing on carbon emissions.

\subsection{The role of institutional pressures on carbon emissions under the mediating effect of top management commitment}

Following Colwell and Joshi's (2013) arguments, we argue that TMC mediates between institutional pressures and carbon emissions. DiMaggio and Powell (1983) argue that coercive pressures (CP), normative pressures (NP) and mimetic pressures (MP) trigger organizational environmental responsiveness by creating a sense of legitimacy around these actions (Colwell and Joshi, 2013). We have grounded our discussion on the basis of Greenwood and Hinings $(1996,1988)$ on the role of intra-organizational dynamics in fostering organizational change in response to external pressures. The two components that are vital for successful organizational change are a commitment to reform and a capacity for change. Colwell and Joshi (2013) argue that both commitment and capacity can be found throughout the organization, but the role of top management is especially critical because it can make the resource allocation and deployment decisions that are necessary to effect change (González-Benito and González-Benito, 2010; Renukappa et al., 2013). Hence, we argue that when TMC is high, institutional pressure for the adoption of practices that may help to reduce the carbon emissions is more likely to be attended to, as it is in line with the organization's vision and more likely to be implemented because the organization has the capabilities that are needed to make the transition from its existing (high-carbon emission) production system to the new (low-carbon emission) production system (Colwell and Joshi, 2013). Hence, we propose:

H1. Coercive pressures under the mediation effect of top management commitment have a significant positive effect on low-carbon emissions in a supply chain.

H2. Normative pressures under the mediation effect of top management commitment have a significant positive effect on low-carbon emissions in a supply chain.

H3. Mimetic pressures under the mediation effect of top management commitment have a significant positive effect on low-carbon emissions in a supply chain.

\subsection{The moderating role of supply base complexity}

Prior research has recognized the role of supply base complexity in organizational performance (Choi and Krause, 2006). In recent years, increasing globalization, offshoring of manufacturing and increase in supplier base have attracted increasing attention of management scholars to address the role of supply base complexity in supply chains. 
However, despite the increasing contributions, the role of supply base complexity in the effect of TMC on environmental sustainability or supply chain sustainability is underdeveloped. The supply base complexity stems from number of suppliers (scale complexity), delivery reliability of suppliers (delivery complexity), differentiation between suppliers and geographic dispersion (Caridi et al., 2010; Brandon-Jones et al., 2014). The complexity of the organizations increases when organizations commit themselves to utilize more diversified suppliers (Bozarth et al., 2009). Organizations need to deploy more resources to manage the flow of information, materials and funds. Kotabe and Murray (2004) argue that the increased instability of the exchange rate in recent years has led to increased difficulties in managing globally scattered suppliers. However, some organizations may successfully explore as well as exploit the opportunities. Edmondson et al. (2003) have noted significant inconsistencies in terms of results related to the effect of TMC on organizational performance. The top management team is often exposed to varied situations. For instance, the asymmetric distributions of information, interest and demographics of the top management team posit an interesting challenge. We therefore argue that the role of TMC in carbon emissions is contingent to specific conditions. Hence, we propose the moderating effect of supply base complexity on the role of TMC in carbon emissions as:

H4. The supply base complexity moderates the relationship between top management commitment and low-carbon emissions in a supply chain.

\section{Research design}

\subsection{Measures}

In our study, we have used a survey-based approach to gather data to test our four research hypotheses. A survey instrument was developed by identifying appropriate measurements from a comprehensive literature review. All of the constructs in the model were operationalized as the reflective constructs as discussed in Table I.

\subsection{Survey instrument}

The theoretical constructs were developed based on extensive literature review. The reflective constructs were measured using a five-point Likert scale with anchors ranging from strongly disagree (1) to strongly agree (5) to ensure high statistical variability among the responses.

Prior to data collection, we pre-tested our instrument following Chen and Paulraj's (2004) suggestions for content validity in two stages. First, we invited six researchers who have published their research works on climate change in reputable journals ( $A B S 3^{*}$ and above) to critique the questionnaire for ambiguity, clarity and appropriateness of the items used to operationalize each construct (Table I). These researchers were asked to assess the extent to which the indicators sufficiently addressed the subject area (Dillman, 1978). Based on the inputs of these researchers, we made modifications to enhance the clarity and appropriateness of the measures to address the constructs.

In the second stage, we e-mailed the questionnaire to 23 materials managers, procurement managers and supply chain managers affiliated with the Indian Institute of Materials Management (IIMM) Pune and Mumbai chapters. These senior executives were asked to review the questionnaire for structure, readability, ambiguity and completeness. The final survey instrument incorporated the inputs from these senior managers, which we believe has enhanced the clarity of the wording in the instrument. The two-stage process yielded a survey instrument that exhibits high content validity.
Low carbon emissions supply chains

713 


\section{IJCCSM \\ 9,5}

714
Table I.

Constructs operationalization

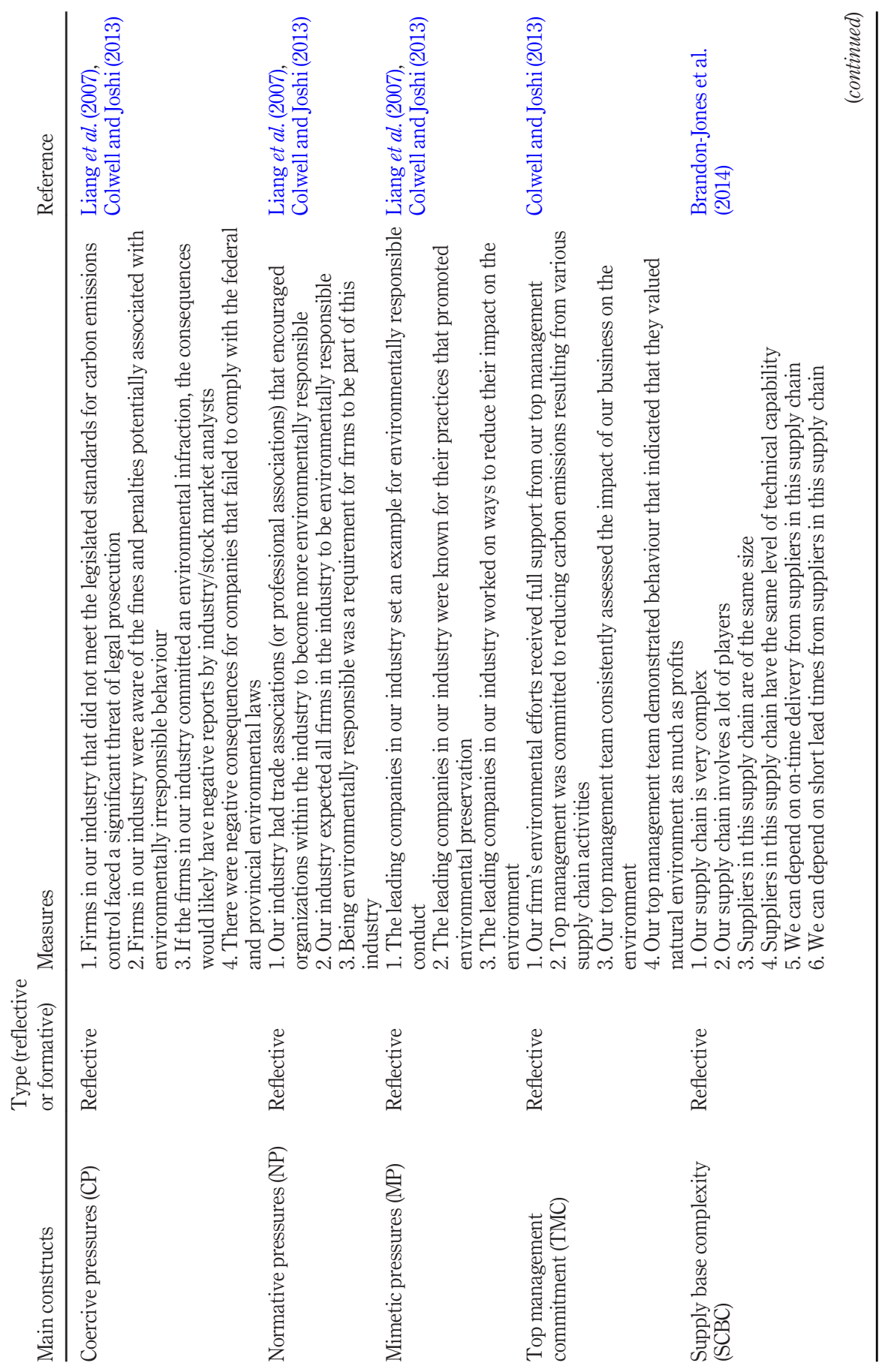




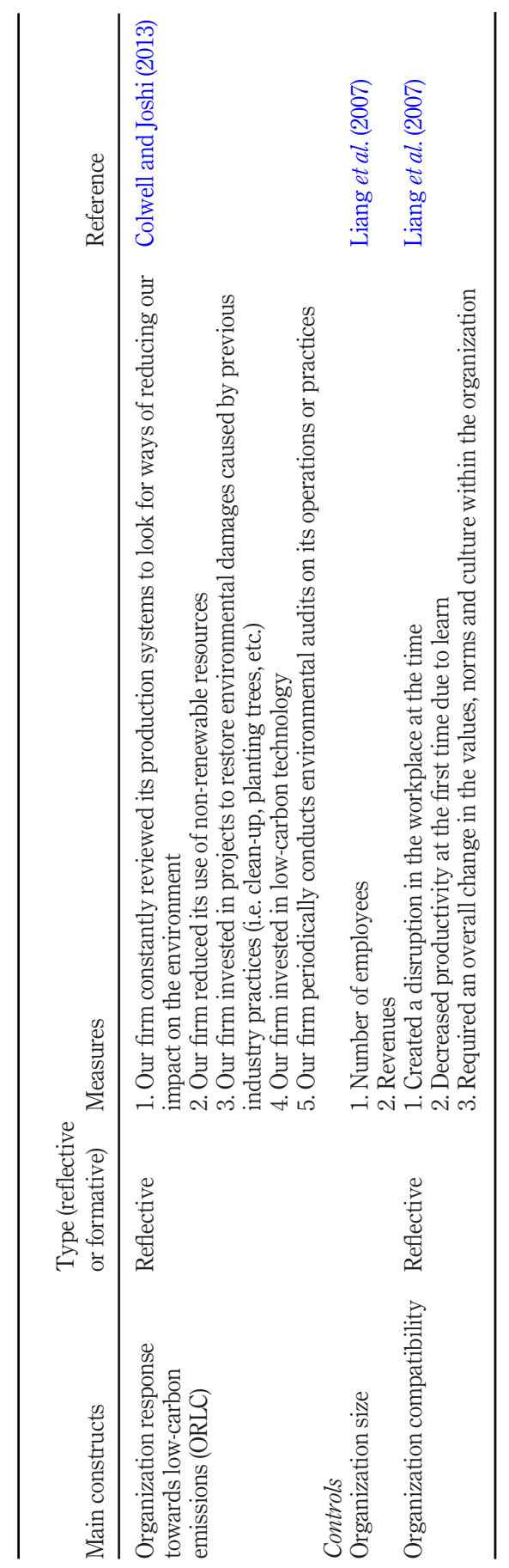

Low carbon emissions supply chains

715 


\section{IJCCSM 9,5}

\subsection{Sampling frame and data collection}

The unit of analysis used in this study was at the level of the manufacturing plant and its constituent suppliers. Prior research has indicated that manufacturing firms provide a detailed understanding of how various activities in a supply chain affect carbon emissions (Jaffe et al., 1995; Klassen and Vachon, 2003; Yang et al., 2011; Zhu and Geng, 2013). The target sample was composed of senior managers included in the IIMM database. We selected 372 potential respondents by their job function (materials manager or equivalent) from five energy-intensive sectors suggested by Smale et al. (2006), i.e. cement, newsprint, steel, aluminium and petroleum.

In an effort to increase the response rate, a modified version of Dillman's (2007) total design test method was followed. Survey questionnaires were sent to the target respondents along with a covering letter via e-mail. One week after the first e-mail, we sent the first reminder via e-mail. After the second week, we received 146 responses. Out of the first 146 responses, we discarded seven responses because of incomplete information. After one month, we sent a second reminder. Within 7 days after we sent the second reminder, we received 42 responses and discarded five responses because of incomplete information. After nine weeks, we received in total 176 usable responses (47.31 per cent). We consider our response rate to be quite satisfactory in comparison to the recent studies in the OSCM field (Eckstein et al., 2015).

To test for non-response bias, we compared the responses of early and late waves of returned surveys following Armstrong and Overton's (1977) suggestions. Student's $t$-tests yielded no statistically significant differences $(\phi=0.45)$ between early-waves (139) and late-waves (37) groups, suggesting that non-response bias was not a problem.

The final sample is described in Table II. It consisted of 21 directors (11.93 per cent), 45 vice-presidents (25.57 per cent) and 110 general managers (62.50 per cent). The respondents were drawn from five different sectors: 34.09 per cent of the respondents were from the cement sector, 11.36 per cent from the newsprint sector, 28.41 per cent from the steel manufacturing sector, 11.93 per cent from the aluminium sector and 14.20 per cent from the petroleum sector. Fifty-six respondents (31.82 per cent) were from those organizations that have more than 1,000 employees and 80 respondents ( 45.45 per cent) were from those organizations that have more than 500 employees but less than 1,000 employees.

Thirty-five respondents (19.89 per cent) were from those organizations that had gross income more than US\$150m, 76 (43.18 per cent) were from those organizations that had gross income more than US $\$ 100 \mathrm{~m}$ but less than US $\$ 150 \mathrm{~m}$ and 65 (36.93 per cent) were from organizations that had gross income less than US\$100m.

\section{Data analyses and results}

Before we proceed further, it is very important that we should check the indicators for the assumption of constant variance, existence of outliers and normality (Dubey et al., 2015; Eckstein et al., 2015). We used plots of residuals by predicted values, rankit plot of residuals and statistics of skewness and kurtosis. The maximum absolute values of skewness and kurtosis of the indicators in the remaining data sets were found to be 1.83 and 4.14 , respectively. These values are well within the limits recommended by past research (univariate statistics <2, kurtosis <7) (Curran et al., 1996; Dubey et al., 2015; Eckstein et al., 2015). Hence, we finally conclude that neither the plots nor the statistics indicated any significant deviances from the assumption. 


\begin{tabular}{|c|c|c|c|}
\hline & Count & $(\%)$ & $\begin{array}{r}\text { Low carbon } \\
\text { emissions }\end{array}$ \\
\hline $\begin{array}{l}\text { Sector } \\
\text { Cement } \\
\text { Newsprint } \\
\text { Steel } \\
\text { Aluminium } \\
\text { Petroleum }\end{array}$ & $\begin{array}{l}60 \\
20 \\
50 \\
21 \\
25\end{array}$ & $\begin{array}{l}34.09 \\
11.36 \\
28.41 \\
11.93 \\
14.20\end{array}$ & supply chains \\
\hline $\begin{array}{l}\text { Number of employees } \\
\text { Less than } 100 \\
101-500 \\
501-1,000 \\
1,000 \text { or more }\end{array}$ & $\begin{array}{l}10 \\
30 \\
80 \\
56\end{array}$ & $\begin{array}{r}5.68 \\
17.05 \\
45.45 \\
31.82\end{array}$ & \\
\hline $\begin{array}{l}\text { Annual sales (\$) } \\
150 \text { million and above } \\
\text { More than } 100 \text { million and less than } 150 \text { million } \\
\text { Less than } 100 \text { million }\end{array}$ & $\begin{array}{l}35 \\
76 \\
65\end{array}$ & $\begin{array}{l}19.89 \\
43.18 \\
36.93\end{array}$ & \\
\hline $\begin{array}{l}\text { Position of the respondents } \\
\text { Directors } \\
\text { Vice-presidents } \\
\text { General managers }\end{array}$ & $\begin{array}{r}21 \\
45 \\
110\end{array}$ & $\begin{array}{l}11.93 \\
25.57 \\
62.50\end{array}$ & $\begin{array}{l}\text { Table II. } \\
\text { Descriptive statistics } \\
\text { of sampling frame }\end{array}$ \\
\hline
\end{tabular}

\subsection{Measurement model}

We conducted confirmatory factor analysis using AMOS 19.0 (see the results displayed in Table III), to estimate the measurement properties of the multi-item reflective constructs used in our hypothesized framework (Figure 1). All the factor loadings were greater than 0.5 standard (Hair et al., 2006), except for CP1 and TMC1, whose factor loadings were lower than 0.4. Hence, we dropped CP1 and TMC1 from further analyses and performed rotation on remaining indicators. We obtained a parsimonious stable structure (Appendix). The measurement model revealed a good fit of the model to the data. We observed the $\left(\kappa^{2} / \mathrm{df}\right)=$ 1.67; CFI (comparative fit index) $=0.98$ and RMSEA (root mean square error of approximation) $=0.06$, each supporting a good model fit.

In support of convergent validity, we observed that all the factor loadings $(\lambda \mathrm{i})$ of remaining indicators were greater than 0.5 , the scale composite reliability (SCR) of each construct used in the hypothesized framework (Figure 1) was $>0.7$ and the average variance extracted (AVE) value was in excess of 0.5 (Fornell and Larcker, 1981; Hair et al., 2006).

For discriminant validity, we compared the construct intercorrelations with AVEs. Table IV displays the bivariate intercorrelations for the constructs of interest to the study.

From Table IV we observe that square root of the AVEs in the leading diagonal of the matrix is greater than the correlation coefficient value in the corresponding row and column, supporting discriminant validity.

\subsection{Common method bias}

Our study utilized survey-based data to test our research hypotheses. However, as with all self-reported data, there is a high risk for common method biases resulting from multiple sources such as consistent motif and social desirability (Podsakoff and Organ, 1986; Podsakoff et al., 2003). Following Podsakoff and Organ (1986), we attempted to enforce a procedural remedy by requesting respondents not to respond to the questions purely on the 


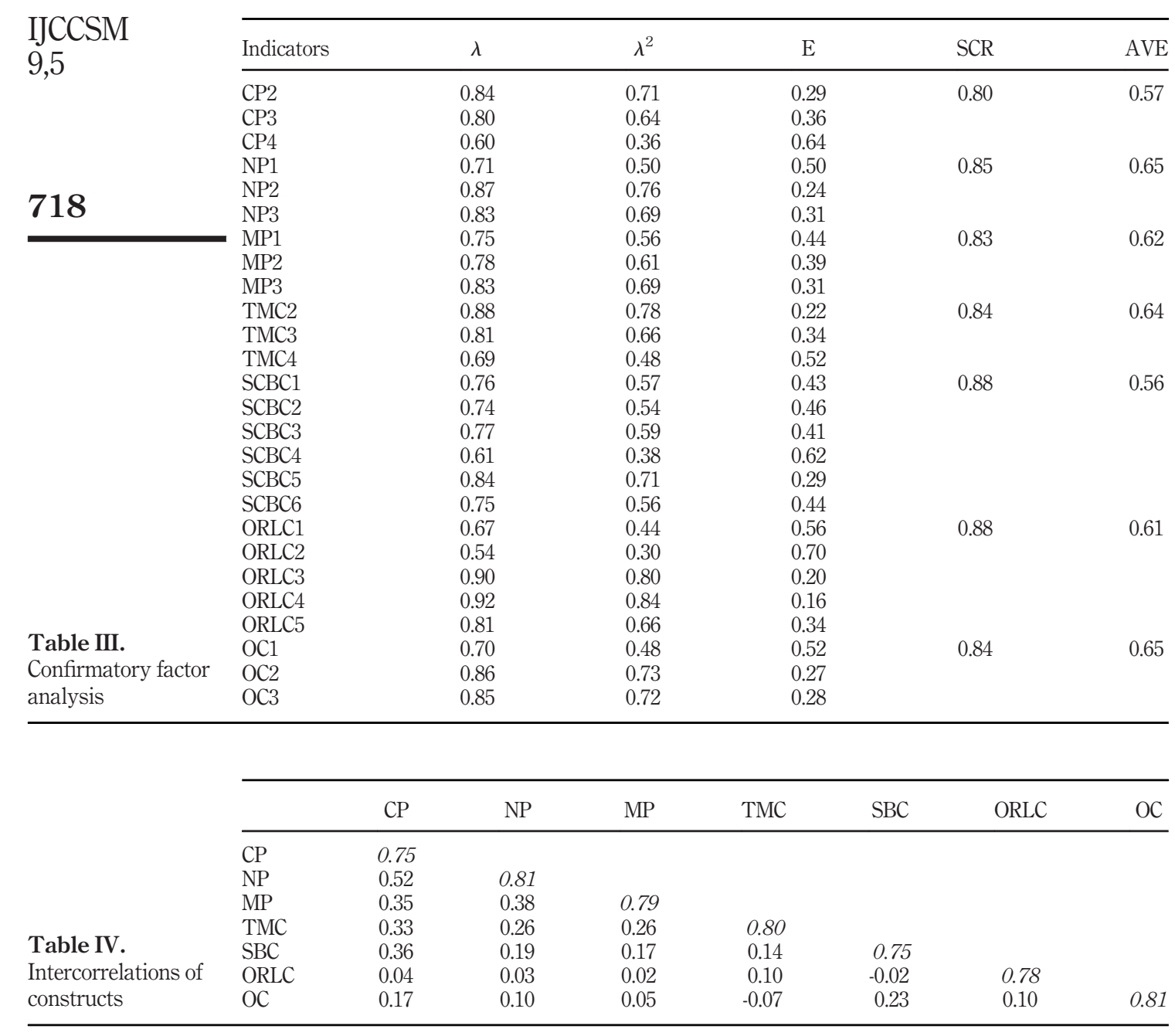

basis of their personal experience but to consult their company documents and minutes of the meetings. In addition, we performed statistical analyses to assess the severity of common method bias. For this we conducted Harman's one-factor test (Podsakoff and Organ, 1986) on seven constructs in our hypothesized framework (Figure 1). The results from this test show that all seven factors are present and the most covariance explained by one factor is 12.88 per cent (Appendix), indicating that common method biases are not likely to contaminate our statistical analyses.

\subsection{Hypothesis testing}

We tested our hypotheses $H 1-H 3$ using regression analysis according to the procedure of Baron and Kenny (1986) (Table V). 


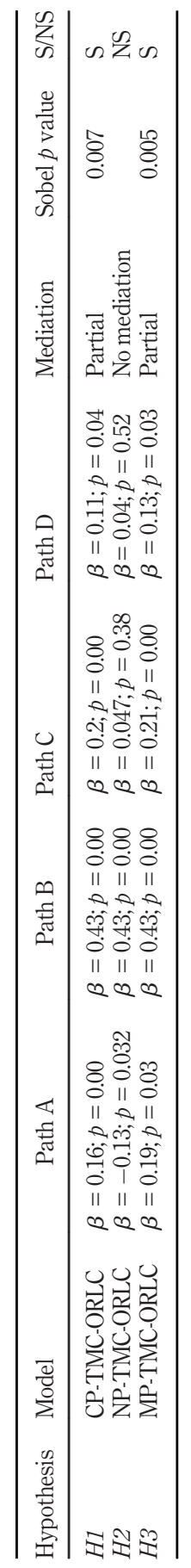

\section{Low carbon emissions supply chains}

Table V. Regression results for mediation test for TMC 
IJCCSM

9,5

720

Addressing H1, we first regressed TMC on $\mathrm{CP}$ (Path A). We observed that $\mathrm{CP}$ has a significant influence on TMC $(\beta=0.16 ; p=0.00)$. The next step was the CP construct (Path $\mathrm{C})$, which showed significant effects on organization response towards low-carbon emissions (ORLC; $\beta=0.2 ; p=0.00$ ). The third regression was ORLC on TMC and CP (Path B and Path D). Path D is the direct effect of CP on ORLC ( $\beta=0.11 ; p=0.04)$, thereby controlling for TMC. Note that direct effect $\mathrm{C}$ is equal to the direct effect $\mathrm{D}$ plus the indirect effect (A times B). The significance of the mediation was determined with the Sobel test (Sobel, 1982). We found support for H1. This result supports prior research (Clemens and Douglas, 2006; Colwell and Joshi, 2013).

For H2, we first regressed TMC on NP (Path A). We observed that NP has a negative influence on TMC ( $\beta=-0.13 ; p=0.032$ ). The next step was the NP construct (Path $\mathrm{C}$ ), which showed insignificant effects on ORLC $(\beta=0.047 ; p=0.38)$. The third regression was ORLC on TMC and NP (Path B and Path D). Path D is the direct effect of NP on ORLC ( $\beta=$ $0.04 ; p=0.52$ ), thereby controlling for TMC. However, we found no support for H2. This finding may open further debates. Hence, in a similar vein to Clemens and Douglas' (2006) arguments, we need to investigate in the context of NP.

Similarly addressing $H 3$, we first regressed TMC on MP (Path A). We observed that MP has a significant influence on TMC $(\beta=0.19 ; p=0.03)$. The next step was the MP construct (Path $\mathrm{C})$, which showed insignificant effects on ORLC $(\beta=0.21 ; p=0.00)$. The third regression was ORLC on TMC and MP (Path B and Path D). Path D is the direct effect of MP on ORLC ( $\beta=0.13 ; p=0.03)$, thereby controlling for TMC. We found support for H3. This result supports prior literature (Bansal, 2005; Colwell and Joshi, 2013).

Next addressing $H 4$, we tested using hierarchical multiple moderation regression (Table VI). The supply base complexity shows significant effects on the path connecting TMC and ORLC $(\beta=0.54 ; p=0.00)$. We found support for $H 4$.

\section{Discussion}

\subsection{Empirical and theoretical implications}

The institutional theory argues that the drive for legitimacy that triggers the processes of institutionalization eventually makes organizations similar without necessarily making them more efficient, giving rise to institutional isomorphism (DiMaggio and Powell, 1983). Institutional theory has attracted significant support from leading scholars (Heugens and

\begin{tabular}{|c|c|c|}
\hline \multirow[b]{2}{*}{ Variables } & \multicolumn{2}{|c|}{ Control model } \\
\hline & $\beta$ & $t$ \\
\hline \multicolumn{3}{|l|}{ Controls } \\
\hline Organizational size & 0.01 & 0.17 \\
\hline Organizational compatibility & 0.64 & 10.80 \\
\hline \multicolumn{3}{|l|}{ Interaction effects } \\
\hline $\mathrm{TMC} \times \mathrm{SCBC}$ & 0.54 & 4.78 \\
\hline \multicolumn{3}{|l|}{ Model summary } \\
\hline & 0.61 & \\
\hline $\operatorname{Adj} R^{2}$ & 0.60 & \\
\hline Model $F$ & 67.23 & \\
\hline$\Delta R^{2}$ & 0.2 & \\
\hline$\Delta F$ & 7.2 & \\
\hline
\end{tabular}

Table VI.

Hierarchical moderated regression results for ORLC 
Lander, 2009). However, unlike any other theories, the institutional theory has attracted criticisms from various scholars. Following Greenwood and Hinings (1996), we note some gaps in the institutional theory. Colwell and Joshi (2013) have attempted to address the gap by arguing the role of TMC in translating external pressures on corporate responsiveness towards environment. However, we argue that a supply chain is a complex network of players that may vary in terms of, for instance, culture, owing to geographic dispersion. Further, Choi and Krause (2006) argue that the differences in terms of cultural, practical and technical aspects may further increase complexity. Following Sousa and Voss (2008), we ground our arguments in the view that if the role of top management is examined using the contingent theory lens, then we may get better explanation for performance in different situations which Colwell and Joshi (2013) have not included in their research model. By examining the moderating role of supply base complexity in the link between TMC and ORLC, we extend the work by Colwell and Joshi (2013). Hence, this study attempts to address Greenwood and Hinings' (1996) concerns related to the use of institutional theory. We argue that integration of three independent theories, that is institutional theory, agency theory and CT, may offer better explanation to the efforts of organizations to minimize the impacts of carbon emissions in a supply chain on environment. Our study, therefore, makes two important contributions to the existing literature. First, we explain the mediating role of TMC in the role of institutional pressures in organizational response towards the environment. Secondly, we argue how supply base complexity may moderate the effect of top management on performance.

\subsection{Managerial implications}

Our findings may offer interesting insights to managers and environmental consultants. The mediating role of TMC clearly suggests the role of the top management team in crafting the vision and translating it into desired success. We note that many organizations, despite their acquisition and use of resources, have failed to align their philosophy in light of the institutional pressures and finally disappeared in the intense competitive era. The role of supply base complexity further provides interesting insights into how managers can positively utilize the suppliers' diversity in terms of culture, linguistics and geographical diversity to address the carbon footprint issues. Our results further indicate that the influence of TMC on ORLC is moderated by supply base complexity. Managers should treat these complexities as a source of competitive advantage.

\subsection{Limitations and future research directions}

First, the current study utilizes cross-sectional data. We note this as one of the limitations of our study. To further advance our study, we recommend further study using longitudinal data. Secondly, we were unable to include supplier-supplier relationships owing to data collection limitations. However, we believe that by using network data, the supplier-suppler relationship can be studied further in relation to supply base complexity. Thirdly, we used the institutional theory perspective to understand how organizations respond to the institutional pressures. However, we believe that in future, we can explore ORLC using strategic choice theory to understand how different types of firms will respond to environment uncertainties. Finally, we observed some limitations in our research design. We believe future studies may benefit from the use of mixed research design (Boyer and Swink, 2008), such as the use of simulation to understand the role of supply base complexity resulting from supplier-supplier relationships in the absence of network data. Similarly, use of multiple case studies may help to build comprehensive theories (Pagell and Wu, 2009). Finally, whereas supply base complexity is utilized as a contingent factor within this
Low carbon emissions supply chains 
IJCCSM

9,5

research, other factors that might moderate the relationship between TMC and ORLC could be examined in future research. We believe, however, that we provide food for thought to those researchers and practitioners who would like to further explore the antecedents of lowcarbon emissions in the supply chain.

\section{Conclusion}

Drawing broadly on institutional theory, the influence of TMC, the contingent effects of supply base complexity and the literature on organizational response towards carbon emissions in supply chain, we developed and tested a theoretical model using cross-sectional data gathered by a pre-tested survey instrument used with Indian manufacturing organizations. The hypothesis tests conducted using multiple regression analyses support our research hypotheses, except $H 2$. The study result supports our argument that under the mediation effect of TMC, CP and MP have positive impacts on ORLC. Hence, our result is a call for further investigation in the context of lack of support, which runs contrary to Colwell and Joshi's (2013) findings. The moderating role of supply base complexity on TMC further highlights the need for strategies to exploit the conditions to produce better performance. Notwithstanding the limitations of this research, our study can be taken to the next level using the research directions we have identified.

\section{References}

Ageron, B., Gunasekaran, A. and Spalanzani, A. (2012), "Sustainable supply management: an empirical study”, International Journal of Production Economics, Vol. 140 No. 1, pp. 168-182.

Armstrong, J.S. and Overton, T.S. (1977), "Estimating nonresponse bias in mail surveys", Journal of Marketing Research, Vol. 14 No. 3, pp. 396-402.

Bansal, P. (2005), "Evolving sustainably: a longitudinal study of corporate sustainable development", Strategic Management Journal, Vol. 26 No. 3, pp. 197-218.

Barney, J. (1991), "Firm resources and sustained competitive advantage", Journal of Management, Vol. 17 No. 1, pp. 99-120.

Baron, R.M. and Kenny, D.A. (1986), "The moderator-mediator variable distinction in social psychological research: conceptual, strategic, and statistical considerations", Journal of Personality and Social Psychology, Vol. 51 No. 6, pp. 1173-1182.

Bode, C., Wagner, S.M., Petersen, K.J. and Ellram, L.M. (2011), "Understanding responses to supply chain disruptions: insights from information processing and resource dependence perspectives", Academy of Management Journal, Vol. 54 No. 4, pp. 833-856.

Benjaafar, S., Li, Y. and Daskin, M. (2013), "Carbon footprint and the management of supply chains: insights from simple models", IEEE Transactions on Automation Science and Engineering, Vol. 10 No. 1, pp. 99-116.

Boyd, B.K., Haynes, K.T., Hitt, M.A., Bergh, D.D. and Ketchen, D.J. (2012), "Contingency hypotheses in strategic management research use, disuse, or misuse?”, Journal of Management, Vol. 38 No. 1, pp. 278-313.

Boyer, K.K. and Swink, M.L. (2008), "Empirical elephants-why multiple methods are essential to quality research in operations and supply chain management", Journal of Operations Management, Vol. 26 No. 3, pp. 338-344.

Bozarth, C.C., Warsing, D.P., Flynn, B.B. and Flynn, E.J. (2009), “The impact of supply chain complexity on manufacturing plant performance", Journal of Operations Management, Vol. 27 No. 1, pp. 78-93. 
Brandon-Jones, E., Squire, B., Autry, C.W. and Petersen, K.J. (2014), "A contingent resource-based perspective of supply chain resilience and robustness", Journal of Supply Chain Management, Vol. 50 No. 3, pp. 55-73.

Caridi, M., Crippa, L., Perego, A., Sianesi, A. and Tumino, A. (2010), "Do virtuality and complexity affect supply chain visibility?”, International Journal of Production Economics, Vol. 127 No. 2, pp. 372-383.

CDP (2015), Supply Chain Sustainability Revealed: A Country Comparison, Supply Chain Report 20142015, CDP, New York, NY, available at: www.cdp.net/CDPResults/CDP-SupplyChain-Report2015.pdf

Chen, F., Drezner, Z., Ryan, J.K. and Simchi-Levi, D. (2000), “Quantifying the bullwhip effect in a simple supply chain: the impact of forecasting, lead times, and information”, Management Science, Vol. 46 No. 3, pp. 436-443.

Chen, I.J. and Paulraj, A. (2004), "Towards a theory of supply chain management: the constructs and measurements", Journal of Operations Management, Vol. 22 No. 2, pp. 119-150.

Choi, T.Y. and Krause, D.R. (2006), "The supply base and its complexity: implications for transaction costs, risks, responsiveness, and innovation", Journal of Operations Management, Vol. 24 No. 5, pp. 637-652.

Chopra, S. and Sodhi, M.S. (2014), "Reducing the risk of supply chain disruptions", MIT Sloan Management Review, Vol. 55 No. 3, p. 73

Clemens, B. and Douglas, T.J. (2006), "Does coercion drive firms to adopt 'voluntary' green initiatives? Relationships among coercion, superior firm resources, and voluntary green initiatives", Journal of Business Research, Vol. 59 No. 4, pp. 483-491.

Colwell, S.R. and Joshi, A.W. (2013), "Corporate ecological responsiveness: antecedent effects of institutional pressure and top management commitment and their impact on organizational performance", Business Strategy and the Environment, Vol. 22 No. 2, pp. 73-91.

Curran, P.J., West, S.G. and Finch, J.F. (1996), "The robustness of test statistics to nonnormality and specification error in confirmatory factor analysis", Psychological Methods, Vol. 1 No. 1, pp. 16-29.

Dacin, M.T., Goodstein, J. and Scott, W.R. (2002), "Institutional theory and institutional change: introduction to the special research forum", Academy of Management Journal, Vol. 45 No. 1, pp. $45-56$.

Delmas, M.A. and Toffel, M.W. (2008), "Organizational responses to environmental demands: opening the black box”, Strategic Management Journal, Vol. 29 No. 10, pp. 1027-1055.

Dillman, D.A. (1978), Mail and Telephone Surveys, Vol. 3, Wiley Interscience, New York, NY.

Dillman, D.A. (2007), Mail and Internet Surveys: The Tailored Design, John Wiley, Hoboken, NJ.

DiMaggio, P. and Powell, W.W. (1983), "The iron cage revisited: collective rationality and institutional isomorphism in organizational fields", American Sociological Review, Vol. 48 No. 2, pp. 147-160.

Donaldson, L. (2001), The Contingency Theory of Organizations, Sage Publications, Thousand Oaks, CA.

Dubey, R., Gunasekaran, A. and Ali, S.S. (2015), "Exploring the relationship between leadership, operational practices, institutional pressures and environmental performance: a framework for green supply chain”, International Journal of Production Economics, Vol. 160, pp. 120-132.

Eckstein, D., Goellner, M., Blome, C. and Henke, M. (2015), "The performance impact of supply chain agility and supply chain adaptability: the moderating effect of product complexity", International Journal of Production Research, Vol. 53 No. 10, pp. 3028-3046.

Edmondson, A.C., Roberto, M.A. and Watkins, M.D. (2003), "A dynamic model of top management team effectiveness: managing unstructured task streams”, The Leadership Quarterly, Vol. 14 No. 3, pp. 297-325. 


\section{IJCCSM 9,5}

Fahimnia, B. and Jabbarzadeh, A. (2016), "Marrying supply chain sustainability and resilience: a match made in heaven", Transportation Research Part E: Logistics and Transportation Review, Vol. 91, pp. 306-324.

Fang, K., Hong, X., Li, S., Song, M. and Zhang, J. (2013), "Choosing competitive industries in manufacturing of China under low-carbon economy: a three-stage DEA analysis", International Journal of Climate Change Strategies and Management, Vol. 5 No. 4, pp. 431-444.

Fornell, C. and Larcker, D.F. (1981), "Evaluating structural equation models with unobservable variables and measurement error", Journal of Marketing Research, Vol. 18 No. 1, pp. 39-50.

González-Benito, J. and González-Benito, Ó. (2010), "A study of determinant factors of stakeholder environmental pressure perceived by industrial companies", Business Strategy and the Environment, Vol. 19 No. 3, pp. 164-181.

Grant, R.M. (1991), "The resource-based theory of competitive advantage: implications for strategy formulation”, California Management Review, Vol. 33 No. 3, pp. 114-135.

Gray, J.V., Roth, A.V. and Leiblein, M.J. (2011), "Quality risk in offshore manufacturing: evidence from the pharmaceutical industry”, Journal of Operations Management, Vol. 29 No. 7, pp. 737-752.

Greenwood, R. and Hinings, C.R. (1988), "Organizational design types, tracks and the dynamics of strategic change”, Organization Studies, Vol. 9 No. 3, pp. 293-316.

Greenwood, R. and Hinings, C.R. (1996), "Understanding radical organizational change: bringing together the old and the new institutionalism”, Academy of Management Review, Vol. 21 No. 4, pp. 1022-1054.

Guha-Sapir, D., Vos, F., Below, R., and Penserre, S. (2012), Annual Disaster Statistical Review 2011: The Numbers and Trends (No. CRED/IRSS), Centre for Research on the Epidemiology of Disasters (CRED), Brussels.

Gupta, P.P., Dirsmith, M.W. and Fogarty, T.J. (1994), "Coordination and control in a government agency: contingency and institutional theory perspectives on GAO audits", Administrative Science Quarterly, Vol. 39 No. 2, pp. 264-284.

Hair, J.F., Black, W.C., Babin, B.J., Anderson, R.E., and Tatham, R.L. (2006), Multivariate Data Analysis, Vol. 6, Pearson, NJ.

Hambrick, D.C. (1983), "High profit strategies in mature capital goods industries: a contingency approach", Academy of Management Journal, Vol. 26 No. 4, pp. 687-707.

Heugens, P.P. and Lander, M.W. (2009), "Structure! Agency! (and other quarrels): a meta-analysis of institutional theories of organization", Academy of Management Journal, Vol. 52 No. 1, pp. 61-85.

Hitchcock, T. (2012), "Low carbon and green supply chains: the legal drivers and commercial pressures”, Supply Chain Management: An International Journal, Vol. 17 No. 1, pp. 98-101.

Hoffman, A.J. (2005), "Climate change strategy: the business logic behind voluntary greenhouse gas reductions", California Management Review, Vol. 47 No. 3, pp. 21-46.

Holweg, M., Reichhart, A. and Hong, E. (2011), "On risk and cost in global sourcing”, International Journal of Production Economics, Vol. 131 No. 1, pp. 333-341.

Hua, G., Cheng, T.C.E. and Wang, S. (2011), "Managing carbon footprints in inventory management", International Journal of Production Economics, Vol. 132 No. 2, pp. 178-185.

Jackson, F. (2014), "Low carbon supply chains for a sustainable future", http://raconteur.net/ sustainability/low-carbon-supply-chains-for-a-sustainable-future (accessed 13 August 2016).

Jaffe, A.B., Peterson, S.R., Portney, P.R. and Stavins, R.N. (1995), "Environmental regulation and the competitiveness of US manufacturing: what does the evidence tell us?", Journal of Economic Literature, Vol. 33 No. 1, pp. 132-163.

Kauppi, K. (2013), "Extending the use of institutional theory in operations and supply chain management research: review and research suggestions", International Journal of Operations \& Production Management, Vol. 33 No. 10, pp. 1318-1345. 
Klassen, R.D. and Vachon, S. (2003), "Collaboration and evaluation in the supply chain: the impact on plant-level environmental investment", Production and Operations Management, Vol. 12 No. 3, pp. 336-352.

Kotabe, M. and Murray, J.Y. (2004), "Global sourcing strategy and sustainable competitive advantage", Industrial Marketing Management, Vol. 33 No. 1, pp. 7-14.

Liang, H., Saraf, N., Hu, Q. and Xue, Y. (2007), "Assimilation of enterprise systems: the effect of institutional pressures and the mediating role of top management", MIS Quarterly, Vol. 31 No. 1, pp. 59-87.

Ling-Yee, L. (2007), "The effects of firm resources on trade show performance: how do trade show marketing processes matter?", Journal of Business \& Industrial Marketing, Vol. 23 No. 1, pp. 35-47.

Melnyk, S.A., Narasimhan, R. and DeCampos, H.A. (2014), "Supply chain design: issues, challenges, frameworks and solutions", International Journal of Production Research, Vol. 52 No. 7 , pp. 1887-1896.

Montoya-Torres, J.R., Gutierrez-Franco, E. and Blanco, E.E. (2015), "Conceptual framework for measuring carbon footprint in supply chains", Production Planning \& Control, Vol. 26 No. 4, pp. 265-279.

Norton, T., Ryan, M. and Wang, F. (2015), "Business action for climate-resilient supply chains: a practical framework from identifying priorities to evaluating impact”, BSR Working Paper, BSR, San Francisco, CA.

Oliver, C. (1997), "Sustainable competitive advantage: combining institutional and resource-based views", Strategic Management Journal, Vol. 18 No. 9, pp. 697-713.

Pacala, S. and Socolow, R. (2004), "Stabilization wedges: solving the climate problem for the next 50 years with current technologies", Science, Vol. 305 No. 5686, pp. 968-972.

Pagell, M. and $\mathrm{Wu}, \mathrm{Z}$. (2009), "Building a more complete theory of sustainable supply chain management using case studies of 10 exemplars", Journal of Supply Chain Management, Vol. 45 No. 2, pp. 37-56.

Podsakoff, P.M., MacKenzie, S.B., Lee, J.Y. and Podsakoff, N.P. (2003), "Common method biases in behavioral research: a critical review of the literature and recommended remedies", Journal of Applied Psychology, Vol. 88 No. 5, pp. 879-903.

Podsakoff, P.M. and Organ, D.W. (1986), "Self-reports in organizational research: problems and prospects", Journal of Management, Vol. 12 No. 4, pp. 531-544.

Renukappa, S., Akintoye, A., Egbu, C. and Goulding, J. (2013), "Carbon emission reduction strategies in the UK industrial sectors: an empirical study", International Journal of Climate Change Strategies and Management, Vol. 5 No. 3, pp. 304-323.

Sarkis, J., Zhu, Q. and Lai, K.H. (2011), “An organizational theoretic review of green supply chain management literature”, International Journal of Production Economics, Vol. 130 No. 1, pp. 1-15.

Seles, B.M.R.P., de Sousa Jabbour, A.B.L., Jabbour, C.J.C. and Dangelico, R.M. (2016), "The green bullwhip effect, diffusion of green supply chain practices, and institutional pressures: evidence from the automotive sector", International Journal of Production Economics, available at: http:// dx.doi.org/10.1016/j.ijpe.2016.08.033

Shaw, K., Shankar, R., Yadav, S.S. and Thakur, L.S. (2013), "Modelling a low-carbon garment supply chain", Production Planning \& Control, Vol. 24 Nos 8/9, pp. 851-865.

Smale, R., Hartley, M., Hepburn, C., Ward, J. and Grubb, M. (2006), "The impact of CO2 emissions trading on firm profits and market prices", Climate Policy, Vol. 6 No. 1, pp. 31-48.

Sobel, M.E. (1982), "Asymptotic confidence intervals for indirect effects in structural equation models", Sociological Methodology, Vol. 13, pp. 290-312.

Sousa, R. and Voss, C.A. (2008), “Contingency research in operations management practices”, Journal of Operations Management, Vol. 26 No. 6, pp. 697-713. 
IJCCSM

9,5

Staw, B.M. and Epstein, L.D. (2000), "What bandwagons bring: effects of popular management techniques on corporate performance, reputation, and CEO pay", Administrative Science Quarterly, Vol. 45 No. 3, pp. 523-556.

Stringfellow, A., Teagarden, M.B. and Nie, W. (2008), "Invisible costs in offshoring services work", Journal of Operations Management, Vol. 26 No. 2, pp. 164-179.

Vachon, S. and Klassen, R.D. (2002), "An exploratory investigation of the effects of supply chain complexity on delivery performance", IEEE Transactions on Engineering Management, Vol. 49 No. 3, pp. 218-230.

Weaver, G.R., Trevino, L.K. and Cochran, P.L. (1999), "Integrated and decoupled corporate social performance: management commitments, external pressures, and corporate ethics practices", Academy of Management Journal, Vol. 42 No. 5, pp. 539-552.

Williamson, O.E. (1981), "The economics of organization: the transaction cost approach", American Journal of Sociology, Vol. 87 No. 3, pp. 548-577.

Yang, M.G.M., Hong, P. and Modi, S.B. (2011), "Impact of lean manufacturing and environmental management on business performance: an empirical study of manufacturing firms", International Journal of Production Economics, Vol. 129 No. 2, pp. 251-261.

Zhao, R., Neighbour, G., Han, J., McGuire, M. and Deutz, P. (2012), "Using game theory to describe strategy selection for environmental risk and carbon emissions reduction in the green supply chain”, Journal of Loss Prevention in the Process Industries, Vol. 25 No. 6, pp. 927-936.

Zhu, Q. and Geng, Y. (2013), "Drivers and barriers of extended supply chain practices for energy saving and emission reduction among Chinese manufacturers", Journal of Cleaner Production, Vol. 40, pp. 6-12.

Zhu, Q. and Sarkis, J. (2007), “The moderating effects of institutional pressures on emergent green supply chain practices and performance", International Journal of Production Research, Vol. 45 Nos 18/19, pp. 4333-4355.

Zhu, Q., Sarkis, J. and Lai, K.H. (2007), "Green supply chain management: pressures, practices and performance within the Chinese automobile industry", Journal of Cleaner Production, Vol. 15 No. 11, pp. 1041-1052.

\section{Further reading}

Bansal, P. and Clelland, I. (2004), “Talking trash: legitimacy, impression management, and unsystematic risk in the context of the natural environment", Academy of Management Journal, Vol. 47 No. 1, pp. 93-103.

Dodds, R. and Graci, S. (2009), "Canada's tourism industry-mitigating the effects of climate change: a lot of concern but little action", Tourism and Hospitality Planning \& Development, Vol. 6 No. 1, pp. 39-51.

Shaw, K., Shankar, R., Yadav, S.S. and Thakur, L.S. (2012), "Supplier selection using fuzzy AHP and fuzzy multi-objective linear programming for developing low carbon supply chain", Expert Systems with Applications, Vol. 39 No. 9, pp. 8182-8192. 


\begin{tabular}{|c|c|c|c|c|c|c|c|c|c|}
\hline & $\mathrm{CP}$ & NP & MP & $\begin{array}{l}\text { Constructs } \\
\text { TMC }\end{array}$ & $\mathrm{SCBC}$ & ORLC & $\mathrm{OC}$ & & \\
\hline \multicolumn{10}{|l|}{$\mathrm{CP} 1$} \\
\hline CP2 & $\begin{array}{l}0.844 \\
0.798\end{array}$ & & & & & & & & 727 \\
\hline $\begin{array}{l}\text { CP3 } \\
\text { CP4 }\end{array}$ & $\begin{array}{l}0.798 \\
0.601\end{array}$ & & & & & & & & \\
\hline NP1 & & 0.707 & & & & & & & \\
\hline NP2 & & 0.872 & & & & & & & \\
\hline NP3 & & 0.831 & & & & & & & \\
\hline MP1 & & & 0.747 & & & & & & \\
\hline MP2 & & & 0.783 & & & & & & \\
\hline MP3 & & & 0.828 & & & & & & \\
\hline \multicolumn{10}{|l|}{ TMC1 } \\
\hline TMC2 & & & & 0.882 & & & & & \\
\hline TMC3 & & & & 0.814 & & & & & \\
\hline TMC4 & & & & 0.694 & & & & & \\
\hline SCBC1 & & & & & 0.756 & & & & \\
\hline SCBC2 & & & & & 0.737 & & & & \\
\hline $\mathrm{SCBC} 3$ & & & & & 0.768 & & & & \\
\hline $\mathrm{SCBC} 4$ & & & & & 0.615 & & & & \\
\hline SCBC5 & & & & & 0.843 & & & & \\
\hline $\mathrm{SCBC} 6$ & & & & & 0.745 & & & & \\
\hline ORLC1 & & & & & & 0.666 & & & \\
\hline ORLC2 & & & & & & 0.544 & & & \\
\hline ORLC3 & & & & & & 0.897 & & & \\
\hline ORLC4 & & & & & & 0.919 & & & \\
\hline ORLC5 & & & & & & 0.810 & & & \\
\hline $\mathrm{OC} 1$ & & & & & & & 0.695 & & \\
\hline $\mathrm{OC} 2$ & & & & & & & 0.857 & & \\
\hline $\mathrm{OC} 3$ & & & & & & & 0.849 & & \\
\hline Eigen Value & 1.71 & 1.95 & 1.86 & 1.92 & 3.35 & 3.05 & 1.94 & 15.78 & Table AI. \\
\hline$(\%)$ & 6.58 & 7.51 & 7.14 & 7.40 & 12.88 & 11.72 & 7.46 & 60.68 & Factors structure \\
\hline
\end{tabular}

\section{Corresponding author}

Rameshwar Dubey can be contacted at: rameshwardubey@gmail.com

For instructions on how to order reprints of this article, please visit our website: www.emeraldgrouppublishing.com/licensing/reprints.htm

Or contact us for further details: permissions@emeraldinsight.com 